\title{
STUDY OF INCREASING GROWTH AND COMPANY VALUE OF PLANTATION SECTOR THROUGH ANALYSIS OF DIVIDEND POLICY AND PROFITABILITY
}

\begin{abstract}
This study aims to be able to analyze the level of influence between the variables of dividend and profitability policies on Corporate Growth and Value. For the purposes of these measurements, financial data from five Plantation Companies in Indonesia that have gone public are used, namely: PT Tunas Baru Lampung, Tbk., PT. Astra Agro Lestari, Tbk., PT. Bakrie Sumatera Plantations, TBK., PT. SMART, Tbk., And PT. PP London Sumatra Plantations 2004 2014.

The target of this study is expected to be able to identify and produce output in the form of value models of plantation companies by considering dividend policy, company growth, and profitability of the Company. The second is to determine the dominant factors that determine the value of the Company in a plantation company.

The analytical method used by the author to analyze dividend and profitability policies on firm value uses the commonly used statistical analysis method, namely, correlation coefficient analysis (r), coefficient of determination analysis (r2) and regression coefficient analysis $(\beta)$. Data were analyzed using regression analysis partially and simultaneously.
\end{abstract}

Key words : dividend policy, profitability, growth and company value. 